\title{
PENGARUH KOMPENSASI DAN BUDAYA ORGANISASI TERHADAP TURNOVER INTENTION
}

\author{
Catur Widayati dan Yolanda Yunia \\ Fakultas Ekonomi Dan Bisnis Universitas Mercu Buana \\ Email: christinewijaya73@yahoo.co.id
}

\begin{abstract}
This study aims to determine the effect of compensation and organizational culture on turnover intention. The object of this study are employees of the company PT HadicoPersada with businesses engaged in outsourcing, located in Central Jakarta. This study was conducted on 47 respondents. The sampling technique used in this study is saturated samples. Therefore, the analysis of the data used is the statistical analysis in the form of multiple linear regression tests. These results indicate that partially, the variable compensation has a negative and significant impact on the variable turnover intention. Variable organizational culture has a significant negative effect on the variable turnover intention.
\end{abstract}

Keywords: Compensation, Organizational Culture, and Turnover Intention.

\begin{abstract}
Abstrak: Penelitian ini bertujuan untuk mengetahui pengaruh kompensasi dan budaya organisasi terhadap turnover intention. Objek penelitian ini adalah karyawan diperusahaan PT Hadico Persada dengan usaha bergerak di bidangoutsource yang berlokasi di Jakarta Pusat. Penelitian ini dilakukan terhadap 47 responden. Teknik sampling yang digunakan dalam penelitian ini adalah sampel jenuh. Karena itu, analisis data yang digunakan adalah analisis statistik dalam bentuk uji regresi linear berganda. Hasil penelitian ini menunjukan bahwa secara parsial, variabel kompensasi mempunyai pengaruh negatif dansignifikan terhadap variabel turnover intention. Variabel budaya organisasi mempunyai pengaruh negatif dan signifikan terhadap variabel turnover intention.
\end{abstract}

Kata kunci: Kompensasi, Budaya Organisasi, dan Turnover Intention.

\section{PENDAHULUAN}

Keberhasilan perusahaan dalam menjalankan usahanya tidak dapat terlepas dari faktor sumber daya manusia (SDM). Terlebih bagi sebuah perusahaan yang menawarkan jasa. Cascio (2007) menegaskan bahwa manusia adalah sumber daya yang sangat penting dalam bidang industri dan organisasi, oleh karena itu pengelolaan sumber daya mencakup penyediaan tenaga kerja yang bermutu, mempertahankan kualitas dan mengendalikan biaya ketenaga kerjaan.Oleh karena itu, SDM adalah aset yang tak ternilai keberadaannya bagi satu perusahaan sehingga harus dipertahankan dan dihindari terjadinya turnover (perpindahan).

Salah satu cara yang dapat dilakukan dalam upaya mengurangi tingkat turnover intention adalah dengan melalui kompensasi dan budya organisasi yang baik untuk mencapai kinerja yang di harapkan dalam suatu organisasi atau instansi, para karyawan harus mendapatkan kompensasi yang cukup dan pengembangan budaya organisasi yang 
baik agar mengurangi atau bahkan untuk mencegah terjadinya turnover intention di perusahaan, manajemen sumber daya manusia sebaiknya lebih memperhatikan dan menerapkan kebijakan terhadap para pekerja agar sesuai dengan kebutuhan dan harapan para pekerja. Debora (dalam sopiah, 2008) Oleh karena itu, perusahaan harus memberi perhatian khusus kepada karyawan dengan berlaku adil sebagai sebuah penghargaan yang diterima atas kontribusi kepada perusahaan. Penelitian ini dilakukan di PT Hadico Persadayang dipimpin oleh HSoewardi Sulaiman selaku Direktur Utama. Dalam penelitian yang akan di teliti adalah karyawan tetap yang ada di PT Hadico Persada. Sebuah perusahaan yang bergerak di bidang outsource. Mengingat lagi kompetitor pada perusahaan yang bergerak di bidang outsource sangatlah banyak. Maka perusahaan tersebut harus mampu mempertahankan Sumber Daya Manusia yang ada.

Fenomena yang terjadi pada pengamatan langsung dan dengan mewawancarai Bapak Deni selaku HRD di PT Hadico Persada beberapa karyawan yang ada di PT Hadico Persada yang dilakukan selama prapenelitian di PT Hadico Persada,yaitu banyaknya turnover karyawan yang terjadi 2 tahun terakhir ini dengan alasan yang beragam salah satunya adalah ingin mencari pekerjaan lain. Dilihat lagi memang perusahaan yang bergerak di bidang outsourcesangatlah banyak dan memiliki masalah tingkat turnover yang tinggi mulai dari karyawan kontrak hingga karyawan tetap, ini didapat dari hasil wawancara dengan manajemen oprasional dan HRD di PT Hadico Persada. Dan dapat di lihat dari data Turnover Karyawan PT Hadico Persada di 2 tahun terakhirdiperoleh pada tahun 2013 jumlah karyawan yang keluar 19\% dan tahun 2014 jumlah karyawan yang keluar mengalami kenaikan hingga $28 \%$.

Salah satu faktor yang melatar belakangi timbulnya masalah ini yaitu disebabkan kurangnya perhatian perusahaan dalam memberikan kompensasi, terutama pemberian upah lemburan yang biasanya diterima karyawan saat ini perusahaan tidak memberikannya dan terkadang pembayaran upah lemburan ini mengalami keterlambatan yang tidak sejalan dalam perjanjian pada awal bekerja dan sering terjadi keterlambatan dalam pemberian gaji. Dari wawancara dengan Pak Deni selaku HRD yang selalu mengadakan evaluasi terhadap karyawan PT Hadico Persada timbul permasalahan yang di dapat dengan keluhan-keluhan tentang kompensasi dan budaya organisasi yang tidak sejalan dengan implementasinya.

Sehubungan dengan permasalahan diatas yaitu mengenai keluhan-keluhan yang di dapat dari pengamatan dan hasil wawancara beberapa karyawan dan HRD PT Hadico Persada dan banyaknya tingkat turnnover intention maka peneliti tertarik untuk melakukan penelitian pada PT HadicoPersada.

\section{KAJIAN TEORI}

Kompensasi. Menurut Hasibuan (2012) Kompensasi adalah semua pendapatan yang berbentuk uang, barang langsung atau tidak langsung yang diterima karyawan sebagai imbalan atas jasa yang diberikan kepada perusahaan.

Indikator Konpensasi. Menurut Hasibuan (2012) kompensasi dibedakan menjadi dua yaitu kompensasi langsung (Direct Compensation) dan kompensasi tidak langsung (Indrirect Compensation). 
Pertama. Kompensasi langsung (Direct Compensation) adalah berupa gaji, upah, dan upah insentif. Gaji adalah balas jasa yang dibayar secara periodik kepada karyawan tetap serta mempunyai jaminan yang pasti. Maksudnya, gaji akan tetap dibayarkan walaupun pekerja tersebut tidak masuk kerja. Upah adalah balas jasa yang dibayarkan kepada pekerja harian dengan berpedoman atas perjanjian yang disepakati membayarnya.

Upah Insentif, adalah tambahan balas jasa yang diberikan kepada karyawan tertentu yang prestasinya diatas prestasi standar. Upah insentif ini merupakan alat yang dipergunakan pendukung prinsip adil dalam pemberian kompensasi.

Kedua. Kompensasi tidak Langsung (Indirect Compensation) adalah kompensasi (balas jasa) langsung merupakan hak bagi karyawan dan menjadi kewajiban perusahaan untuk membayarnya. Benefit dan Service adalah kompensasi tambahan yang di berikan berdasarkan kebijaksanaan perusahaan terhadap semua karyawan dalam usaha untuk meningkatkan kesejahteraan mereka. Seperti tunjangan hari raya, fasilitas kantor, pakaian dinas, mushala, olahraga, dan darmawisata.

Budaya Organisasi. Menurut Robbins dalam (Sopiah, 2008) mendefinisakan bahwa "Budaya organisasi adalah sistem makna bersama yang dianut oleh anggota-anggota yang membedakan organisasi itu dari organisasi-organisasi lain".

Indikator Budaya Organisasi. Menurut Robbins dalam (Sopiah, 2008) ada tujuh karakteristik utama yang secara keseluruhan merupakan hakikat budaya organisasi, diantaranya: (1) Inovasi dan pengambilan resiko. Dilihat dari sejauh mana para karyawan didorong untuk bersikap inovatif dan kreatif dan berani mengambil resiko. (2) Perhatian ke hal yang rinci. Sejauh mana para karyawan mau memperlihatkan kecermatan, analisis dari perhatian kepada rincian. (3) Orientasi hasil. Sejauh mana manajemen fokus pada hasil, bukan pada teknik dan proses yang digunakan untuk mendapatkan hasil itu. (4) Orientasi orang. Sejauh mana keputusan manajemen memperhitungkan efek hasil pada orang-orang di dalam organisasi itu. (5) Orientasi tim. Sejauh mana kegiatan kerja diorganisasikan dalam tim-tim kerja, bukannya individu-individu. (6) Keagresifan. Sejauh mana orang-orang itu agresif dan kompetitif, bukan bersantai. (7) Kemantapan. Sejauh mana kegiatan organisasi menekankan dipertahankannya status quo sebagai lawan dari pertumbuhan atau inovasi.

Dengan menilai organisasi itu berdasarkan tujuh karakteristik ini, akan diperoleh gambaran majemuk dari budaya organisasi itu. Gambaran ini menjadi dasar untuk perasaan pemahaman bersama yang dimiliki para anggota mengenai organisasi itu, bagaimana urusan diselesaikan di dalamnya, dan cara para anggota berperilakuRobbins dalam (Sopiah, 2008).

Turnover Intention. Menurut (Deborah, 2008) menyatakan bahwa intensi keluar merupakan variabel yang paling berhubungan dan lebih banyak menjelaskan perilaku turnover.

Indikator Turnover Intention. Menurut Deborah (2008) menyatakan bahwa intensi keluar merupakan variabel yang paling berhubungan dan lebih banyak menjelaskan perilaku turnover, dimana keinginan untuk keluar dapat diukur dengan tiga komponen berikut ini: Pertama. Keinginan untuk mencari pekerjaan baru di bidang yang sama di perusahaan lain. Melihat adanya perusahaan lain yang dirasa mampu memberikan 
keuntungan lebih banyak dibandingkan tempat dia bekerja saat ini, dapat menjadi alasan utama bagi individu untuk memicu keinginannya keluar dari perusahaan. Namun hal itu akan terbatas di saat dia hanya akan menerima jika sesuai dengan keahliannya saat ini. Kedua. Keinginan untuk mencari pekerjaan baru di bidang yang berbeda di perusahaan lain. Seorang individu yang merasa selama ini kurang mengalami kemajuan pada pekerjaan akan mencoba untuk beralih pada bidang yang berbeda. Tanpa harus mempelajari keahlian baru, individu tersebut mencari pekerjaan di bidang yang baru dengan keahlian sama dengan yang dia miliki saat ini. Ketiga. Keinginan untuk mencari profesi baru. Dengan memiliki keahlian yang cukup banyak, maka akan mudah bagi seseorang untuk timbul keinginan mencari pekerjaan baru yang sebelumnya tidak pernah dia kerjakan.

\section{Penelitian Terdahulu}

1) Penelitian yang di lakukan Edward, Johannes, dan Rofi'I,Muchid (2014) dari Jurnal Dinamika Manajemen Vol.2 No.2 April-Juni 2014 ISSN: 2338-123X, 141-152 dengan judul penelitian "Pengaruh Kompensasi dan Iklim Organisasi Terhadap Turnover Intention Dengan Kepuasan Kerja Sebagai Variabel Intervening di PT Trimitra Lestari". Penelitian ini bertujuan untuk memeriksa pengaruh kompensasi dan iklim organisasi terhadap niat pindah (turnover intention) dimana kepuasan kerja sebagai variabel intervening di PT Trimitra Lestari. Populasi di dalam penelitian ini adalah 124 karyawan. Sampel penelitian ditentukan berdasarkan ketentuan lima kali atas variabel pelanggn. Dengan demikian, dengan jumlah variabel 23 maka besaran sampel adalah 5 kali 23 yaitu 11 unit. Pemilihan sampel dilakukan dengan sistem acak sederhana. Metode analisis data yang di gunakan adalah Structural Equation Modeling (SEM). Hasil penelitian menunjukkan bahwa: kompensasi berpengaruh positif dantidaksignifikan terhadap kepuasan kerja yang akan meningkatkan niat untuk pindah, iklim organisasi mempunyai pengaruh positif tetapi kurang signifikan terhadap kepuasan kerja yang akan meningkatkan niat untuk pindah, dan kepuasan kerja mempunyai pengaruh negatif dan signifikan yang akan meningkatkan terhadap niat untuk pindah.

2) Penelitian yang dilakukan oleh Putrianti, Arin Dewi (2014) dari Jurnal Administrasi Bisnis (JAB) Vol. 12 No. 2 Juli 2014 hal.1-9 dengan judul penelitian "Pengaruh Kompensasi dan Motivasi Kerja Terhadap Turnover Intention (Studi Pada Karyawan PT TIKI Jalur Nugraha Ekakurir Pusat Malang)". Penelitian ini bertujuan untuk mengetahui pengaruh variabel Kompensasi dan Motivasi Kerja, secara parsial dan simultan terhadap Turnover Intention pada PT TIKI Jalur Nugraha Ekakurir Pusat Malang. Sampel yang digunakan dalam penelitian yaitu pada karyawan PT TIKI Jalur Nugraha Ekakurir Pusat Malang adalah sebanyak 62 orang. Jenis penelitian ini adalah explanatory research dengan pendekatan kuantitatif dan dilakukan dengan metode kuesioner. hasil penelitian ini diketahui adanya pengaruh yang signifikan dari kompensasi dan motivasi kerja terhadap turnover intention. Kompensasiberpengaruhnegativedansignifikanterhadapturnover intention karyawan di PT TIKI Jalur Nugraha Ekakurir Pusat Malang, dan dari sini dapat diketahui bahwa kedua variabel bebas tersebut yang dominan pengaruhnya terhadap turnover intention adalah kompensasi karena nilai koefisien beta yang lebih besar. 
3) Penelitian yang di lakukan oleh Kadiman (2012) dari JURAKSI Vol.1 Januari 2012 ISSN : 2301-9328, 57-72 dengan judul "Pengaruh Budaya Organisasi, Komitmen Organisasi dan Kepuasan Kerja Terhadap Turnover Intention Karyawan (Studi Kasus pada PT Nyonya Meneer Semarang)". Penelitian ini bertujuan untuk mengetahui Pengaruh Budaya Organisasi, Komitmen Organisasi dan Kepuasan Kerja Terhadap Turnover IntentionKaryawan (Studi Kasus pada PT Nyonya Meneer Semarang). Populasi dalam penelitian ini adalah karyawan PT Nyonya Meneer Semarang, teknik pengumpulan sampel dengan menggunakan cara accidental sampling dan sampel yang di ambil sebanyak 115 karyawan. Metode analisis menggunakan metode regresi liner berganda untuk menguji pengaruh dua atau lebih variabel independen. Hasil penelitian ini menunjukan bahwa ada pengaruh yang negatif dan signifikan antara budaya organisasi dengan turnover intention, komitmen berpengaruh negative dan signifikanterhadapturnover intention, dan kepuasan kerja berpengaruh negatif signifikan terhadap turnover intention. Dengan tabel summary menunjukan angka koefisien determinasi berganda $\left(\mathrm{R}^{2}\right)$ sebesar 0,614 . Hal ini berarti besar $61,4 \%$ dapat di jelaskan oleh variabel budaya organisasi, komitmen organisasi (komitmen afektif, komitmen kontinyu, dan komitmen normatif) dan kepuasan kerja, sedangkan sisanya sebesar 38,6 di jelaskan oleh sebab lain di luar variabel yang di teliti.

4) Penelitian yang di lakukan oleh Johartono dan Widuri, Retnaningtyas (2013) dari Tax \& Accounting Review, VOL. 3, NO.2, 2013, hal.1-13, dengan judul "Analisa Pengaruh Stres Kerja, Kepuasan Kerja, Budaya Organisasi, Dan Komitmen Organisasi Terhadap Turnover Intention Karyawan Kantor Konsultan Pajak di Surabaya". Penelitian ini bertujuan untuk mengetahui apakah stres kerja, kepuasan kerja, budaya organisasi, dan komitmen organisasi mempunyai pengaruh yang signifikan terhadap turnover intention karyawan kantor konsultan pajak di Surabaya baik secara parsial maupun secara simultan. Data diperoleh dari kuesioner yang disebar ke 100 responden yang merupakan karyawan kantor konsultan pajak di Surabaya pada bulan Mei 2014. Sebanyak 100 kuesioner kembali dengan keadaan yang lengkap dan dapat diolah. Dengan menggunakan teknik analisa regresi berganda. Hasil penelitian ini menunjukan bahwa terdapat hubungan positif signifikan antara stres kerja dengan turnover intention. Di mana jika stres kerja yang dirasakan karyawan menurun, maka tingkat turnover intention juga bisa jadi akan menurun. Selain itu terdapat hubungan negatif signifikan antara variabel kepuasan kerja, budaya organisasi, dan komitmen organisasi terhadap turnover intention. Semakin tinggi tingkat yang dirasakan karyawan atas kepuasan kerja, budaya organisasi dan keinginan untuk berkomitmen di tempatnya bekerja, maka semakin rendah tingat turnover intention karyawan yang akan terjadi.

5) Penelitian yang di lakukan Irbayuni, Sulastri (2012) dari Jurnal NeO-Bis Volume 6, No.1, Juni 2012, hal.1-12, dengan judul penelitian "Pengaruh Kopensasi,Kepuasan Kerja, dan Komitmen Organisasi terhadap Keinginan Untuk Pindah Kerja pada PT Surya Sumber Daya Energi Surabaya”. Penelitian ini bertujuan untuk memeriksaPengaruh Kopensasi,Kepuasan Kerja, dan Komitmen Organisasi terhadap Keinginan Untuk Pindah Kerja pada PT Surya Sumber Daya Energi Surabaya. Populasi di dalam penelitian ini adalah seluruh karyawan PT Surya Sumber Daya Energi Surabaya yang berjumlah 177 karyawan. Dan tidak semua di jadikan sampel. Sampel penelitian ditentukan berdasarkan ketentuan lima kali atas variabel pelanggn. 
Teknik sampling yang di gunakan adalah sample random sampling dengan memperhatikan faktor-faktor karyawan pada bagian produksi, marketing, dan pengiriman yang telah bekerja selama 2 tahun. Metode analisis data yang di gunakan adalah Structural Equation Modeling (SEM). Hasil penelitian menunjukkan bahwa Kompensasi berpengaruh tidak signifikan terhadap Keinginan Untuk Pindah Kerja Karyawan, Kepuasan Kerja berpengaruh positif dan tidak signifikan terhadap Keinginan Untuk Pindah Kerja Karyawan, dan Komitmen Organisasi berpengaruh negatif dan signifikan terhadap Keinginan Untuk Pindah Kerja Karyawan.

6) Penelitian yang dilakukan E. Jacobs and G. Roodt (2008) dari Article In Health Sa Gesondheid· January 2008 DOI : 10.4102 /hsag. v13i1.258 Source: DOAJ hal. 1-11, melakukan penelitian yang berjudul "Organisational culture of hospitals to predict turnover intentions of professional nurses". Penelitian ini bertujuan untuk menentukan apakah budaya organisasi memprediksi turnover intention pada perawat profesional. Populasi sasaran adalah perawat profesional yang bekerja di rumah sakit. Persyaratan adalah bahwa perawat tersebut harus dianggap sebagai profesional dan terdaftar seperti itu. Staf atau asisten perawat tidak termasuk dalam populasi target. Berbagai tantangan penting dan masalah harus ditujukan untuk menentukan kerangka sampling dan unit analisis. Menurut angka oleh Dewan Keperawatan Afrika Selatan (2004), ada sekitar 93.000 terdaftar perawat profesional di Afrika Selatan. (Angka ini tidak harus bingung dengan estimasi 155.400 jika staf perawat juga diambil dalam pertimbangan). Metode sampling yang digunakan korelasi adalah pertama untuk menguji hipotesis dan kedua untuk menganalisis variabel untuk mengusulkan model teoritis. Hasil penelitian ini menunjukan bahwa Tujuan dari penelitian ini adalah untuk menentukan apakah budaya organisasi memprediksi turnover intention pada perawat profesional. Dan terdapat hasil yang negatif dan signifikan antara budaya organisasi dengan turnover intention. Sebuah model prediksi dengan budaya organisasi dan berbagai variabel mediasi yang diusulkan, yaitu berbagi pengetahuan, komitmen organisasi, organisasi perilaku citisenship dan kepuasan kerja, serta berbagai variabel demografis dikembangkan untuk menentukan turnover intention melalui menerapkan Umum Pemodelan Linear.

7) Penelitian yang di lakukan oleh Marshall Egan, Toby, Baiyin, R. Bartlett, Kenneth (2004). Human Resource Development Quarterly, vol. 15, no. 3, Fall 2004, hal.279301, melakukan penelitian yang berjudul "The Effects of Organizational Learning Culture and Job Satisfaction on Motivation to Transfer Learning and Turnover Intention".Penelitian ini menguji hubungan budaya organisasi, kepuasan kerja, dan variabel hasil organisasi dengan sampel teknologi informasi (IT) karyawandi Amerika Serikat. Populasi dalam penelitian adalah Semua pekerja IT di perusahaan-perusahaan besar AS. Sampel untuk studi ini diambil dari ReferenceUSA, database onlineyang menyediakan informasi mengenai lebih dari 12 juta bisnis di Amerika Serikat. Total dari 3.336 perusahaan di seluruh Amerika Serikat dari database memiliki lima ratus atau lebih banyak karyawan dan karena itu memenuhi kriteria seleksi. Metode penelitian ini adalah memakai Structural equation modeling (SEM). Hasil penelitian ini di dapat bahwa budaya belajar organisasi dan kepuasan kerja yang penting dalam menentukan motivasi karyawan untuk mentransfer pembelajaran dan turnover intention. Hasil penelitian ini menunjukkan bahwa budaya organisasi belajar memiliki pengaruh yang signifikan pada kedua kepuasan kerja dan motivasi untuk mentransfer 
pembelajaran, dan bahwa dampak langsung dari kepuasan kerja terhadap motivasi untuk mentransfer pembelajaran adalah positif tetapi tidak signifikan Itu juga menemukan bahwa budaya organisasi berdampak langsung pada turnover intention karyawan.

8) Penelitian yang di lakukan oleh Devi, Ni Luh Mita SridanSudibia, GedeAdnyana (2015) dari E-Jurnal Manajemen Unud, Vol. 4, No. 4, 2015:1047-1066 ISSN : 23028912dengan judul "Analisis Pengaruh Job Insecurity dan Kompensasi Finansial Terhadap Kepuasan Kerja dan Turnover Intention (Studi pada Karyawan Kontrak di Balidynasty Resort)". Penelitian ini bertujuan untuk menganalisis pengaruh job insecurity dan kompensasi financialterhadap kepuasan kerja dan turnover intention karyawan kontrak di Bali Dynasty Resort.. Populasi dalam penelitian ini adalah karyawan tetap dan kontrak pada Bali Dynasty Resort sebanyak 373 orang. Metode analisis menggunakan metodeteknik analisis jalur (Path Analysis). Berdasarkan hasil analisis disimpulkan variabel job insecurity memiliki pengaruh positif dan signifikan terhadap kepuasan kerja, variabel job insecurity memiliki pengaruh yangnegatif dan signifikan terhadap kepuasan kerja, kompensasi financial berpengaruh positifterhadap kepuasan kerja, variabel kompensasi financial memiliki pengaruh negatif dansignifikan terhadap turnover intention, variabel kepuasan kerja memiliki pengaruh negatif dansignifikan terhadap turnover intention. Implimentasi dari penelitian ini bahwa untuk menghindari keinginan karyawan untuk mencari pekerjaan baru di perusahaan lain dapat dilakukan dengan menerapkan jenjang karir bagi karyawan tersebut sehingga karyawan kontrak merasa bahwa pekerjaan mereka memiliki keuntungan lebih di masa yang akan datang.

9) Penelitian yang di lakukan olehMalik, Alfian (2014) dari eJournal Psikologi, 2014, 2 (1): 65-75 ISSN 0000-0000, ejournal.psikologi.fisip-unmul.ac.id, dengan judul "Pengaruh Budaya Organisasi dan Loyalitas Kerja dengan Intensi Turnover pada Karyawan PT Cipaganti Heavy Equipment Samarinda". Penelitian ini bertujuan untuk menganalisis pengaruh budaya organisasi dan loyalitas kerja dengan intensi turnover pada karyawan PT Cipaganti Heavy Equipment Samarinda. Populasi dalam penelitian ini adalahKaryawan PT Cipaganti Heavy Equipment Samarinda dengan sampel 71 orang karyawan. Metode analisis menggunakanregresi model ganda dan uji regresi model stepwise, dengan skala pengukuran adalah skala likert. Berdasarkan hasil analisis disimpulkan variabel budaya organisasi dan loyalitas kerja terhadap intensi turnover memiliki pengaruh positif dan signifikan, variabel budaya organisasi dengan intensi turnover memiliki pengaruh positif dan tidak signifikan, dan loyalitas kerja dengan intensi turnover memiliki pengaruh positif dan signifikan.

10) Penelitian yang di lakukan olehBibowo, Adi dan Masdupi, Erni (2015) dari Jurnal Riset Manajemen Bisnis dan Publik, Vol 3, No 3, 2015 , 1-16, dengan judul "Pengaruh Kepuasan Kerja, Kompensasi, dan Pengembangan Karir terhadap Turnover Intention pada Karyawan Bank Syariah Mandiri cabang Padang". Penelitian ini bertujuan untuk menentukan pengaruh kepuasan kerja, kompensasi, dan pengembangan karir terhadap turnover intention pada Karyawan Bank Syariah Mandiri cabang Padang. Populasi dalam penelitian ini adalah karyawan BSM cabang Padang dengan jumlah 84 karyawan sebagai sampel penelitian, Teknik pengambilan sampling adalah rumus Slovin dan dipilih dengan menggunakan cluster random sampling techniqe, dengan metode analisis regresi. Hasil penelitian ini menunjukkan 
bahwa kompensasi dan pengembangan karir yang positif dan signifikan mempengaruhi pekerjaan kepuasan. Selanjutnya, kompensasi, pengembangan karir dan kepuasan pekerjaan semua bersama-sama memiliki pengaruh yang signifikan terhadap turnover intention tapi individual hanya kepuasan kerja yang memiliki pengaruh yang signifikan dan negatif untukomset niat.

\section{Rerangka Konseptual}

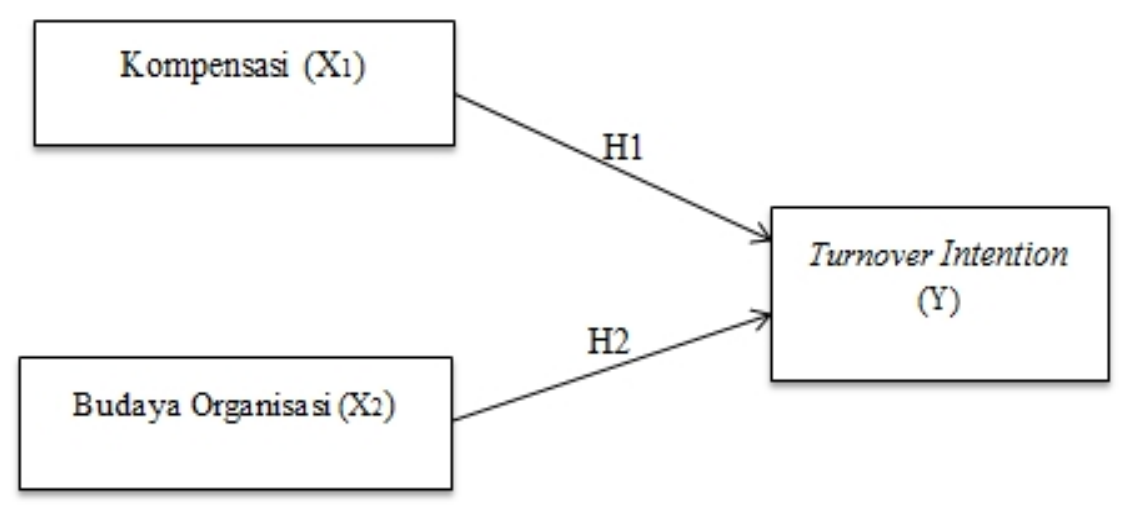

Gambar 1. Rerangka Pemikiran

\section{Hipotesis}

Pengaruh Kompensasi terhadap Turnover Intention. Penelitian yang di lakukanoleh Putrianti, Arin Dewi (2014). Berdasarkan hasil analisis untuk variable kompensasi ,hal ini menunjukan bahwa kompensasi mempunyai kontribusi yang besar dalam menurunkan turnover intention. Hasill uji coba Putrianti, Arin Dewi membuktikan bahwa kompensasi berpengaruh signifikan terhadap turnover intention. Penelitian tersebut sejalan dengan yang dilakukan oleh Devi, Ni Luh Mita Sri dan Sudibia, Gede Adnyana (2015) ditemukan bahwa kompensasi financial berpengaruh signifikan hal ini menunjukan bahwa semakin besar kompensasi finansial yang diterima, niat untuk keluar dari pekerjaan akan berkurang karena karyawan merasa dihargai dengan kebutuhannya yang dapat terpenuhi, sebaliknya rendahnya kompensasi finansial yang diterima maka turnover intention akan semakin tinggi sehingga kompensasi akan sangat berguna jika diberikan dengan pengorbanan yang karyawan berikan kepadap erusahaan. Hasil uji coba yang di dapat dari Devi, Ni Luh Mita Sri dan Sudibia, Gede Adnyana (2015) bahwa kompensasi berpengaruh signifikan terhadap turnover intention. Bedasarkan pernyataan di atas maka dapat dirumuskan hipotesis sebagaiberikut :

H1 : Kompensasi berpengaruh signifikan terhadapturnover intention.

Pengaruh Budaya Organisasi terhadap Turnover Intention. Menurut Kadiman (2012) bahwa budaya organisasi mempunyai pengaruh terhadap turnover intention. Hal ini berarti bahwa karyawan dengan budaya organisasi yang tinggi akan memiliki keinginan untuk berpindah kerja yang lebih kecil. Upaya organisasi untuk penutunan perilaku karyawan, pada dasarnya adalah melakukan pemberdayaan sember daya manusia atau karyawan seefektif mungkin, namun dengan mendasarinya pada budaya organisasi yang tepat. Hasil 
uji coba yang di lakukan oleh Kadiman bahwa ada pengaruh signifikan antara Budaya Organisasi terhadap Turnover Intention.

Menurut Johartono dan Widuri, Retnaningtyas (2013) bahwa budaya organisasi mempunyai pengaruh terhadap turnover intention. Hal ini di tunjukan bahwa Dalam penelitian ini digunakan 4 fungsi budaya organisasi untuk mengukur apakah tingkat budaya organisasi yang dirasakan oleh karyawan sudah tinggi atau tidak. Dari hasil penelitian, angka untuk budaya organisasi tergolong cukup tinggi, terutama pada bagian fungsi sebagai komitmen kolektif. Di mana para karyawan merasa bangga menjadi bagian dari perusahaan yang tidak terpisahkan. Hal ini terjadi karena adanya pengakuan dan kesempatan pada karyawan untuk mengembangkan diri. Hasil uji coba Johartono dan Widuri, Retnaningtyas bahwa pengaruh budaya organisasi terhadap turnover intention memiliki pengaruh yang signifikan.

Bedasarkan pernyataan di atas maka dapat dirumuskan hipotesis sebagai berikut :

H2 : Budaya Organisasi berpengaruh signifikan terhadap Turnover Intention.

\section{METODE}

Waktu \& Tempat Penelitian. Penelitian ini di lakukan mulai dari akhir agustus hingga september 2015. Pelaksanaan penelitian ini penulis mengambil tempat penelitian pada PT Hadico di Jl Mardani Raya 6-9, Johar Baru, Cempaka Putih, Jakarta 10560, Jakarta, Indonesia Untuk memperoleh data guna penyusunan skripsi.

Desain Penelitian. Desain penelitian yang digunakan penulis dalam penelitian ini menggunakan penelitian kausal. Kausal adalah hubungan yang bersifat sebab akibat dimana variabel independen mempengaruhi variabel dependen (Sugiyono, 2013). Penelitian ini merupakan penelitian untuk mengetahui pengaruh dua variabel independen yaitu kompensasi dan budaya organisasi terhadap variabel dependen yaitu Turnover Intention. Dalam hal ini penelitian bertujuan untuk mengetahui pengaruh kompensasi dan budaya organisasi terhadap turnover intention di PT Hadico Persada di cabang Jakarta.

Skala Pengukuran Variabel. Pengukuran variabel dalam penelitian ini menggunakan skala likert yang digunakan untuk mengukur sikap, pendapat dan persepsi seseorang atau sekelompok orang tentang fenomena social (Sugiyono, 2013).Dengan tikatan skala yang digunakan adalah dari nilai 1 sampai dengan 5 dari sangat tidak setuju, ragu-ragu, setuju, dan sangat setuju (Sugiyono, 2013).

Populasi dan Sampel Penelitian. Menurut Sugiyono (2013) yang dimaksud dengan populasi adalah wilaya hgeneralisasi yang terdiri atas subyek dan obyek yang mempunyai kualitas dan karakteristik tertentu yang ditetapkan oleh peneliti untuk dipelajari dan kemudian ditarik kesimpulannya. Dalam penelitian ini populasi adalah seluruh karyawan PT Hadico Persada yang berjumlah 47 orang. Sampel adalah bagian dari jumlah dan karakteristik yang dimiliki oleh populasi tersebut (Sugiyono, 2013). Cara pengambilan sample dalam penelitian ini menggunakan teknik sampling jenuh. Teknik sampel jenuh dimana penentuan sampel dilakukan oleh semua anggota populasi dikarenakan jumlah populasi yang relatif kecil.

Metode Pengumpulan Data. Dalam penelitian ini teknik pengumpulan data yang digunakan yaitu dengan penelitian lapangan (Field research) dengan melakukan 
penyebaran kuisioner. Jenis data yang digunakan oleh penulis adalah data primer yang berupa dari hasil kuisioner tentang kompensasi, komitmen organisasis dan turnover intention. Dalam hal ini penulis menggunakan kuisioner.

Teknik analisis data dalam penelitian ini adalah analisis regresi linier berganda dengan menggunakan program IBM SPSS Statistik Versi 21.0

\section{HASIL DAN PEMBAHASAN}

Hasil Uji Koefisien Determinasi $\mathbf{R}^{2}$. Koefisian Determinasi $\left(\mathrm{R}^{2}\right)$ pada intinya mengukur seberapa jauh kemampuan model dalam menerangkan variabel-variabel dependen.Nilai koefisian determinasi adalah antara nol sampai dan satu. Nilai determinasi ditentukan dengan nilai Adjusted R Square. Hasil pengujian koefisian determinasi $\mathrm{R}^{2}$ dapat dilihat pada Tabel 1.

Tabel 1. Hasil Uji Koefisian Determinasi $\mathrm{R}^{2}$

\begin{tabular}{|c|c|c|c|c|}
\hline \multicolumn{5}{|c|}{ Model Summary } \\
\hline Model & $\mathrm{R}$ & R Square & $\begin{array}{l}\text { Adjusted R } \\
\text { Square }\end{array}$ & $\begin{array}{l}\text { Std. Error of } \\
\text { the Estimate }\end{array}$ \\
\hline 1 &, $638^{\mathrm{a}}$ & ,407 & ,480 & 5,811 \\
\hline
\end{tabular}

Berdasarkan Tabel 1 dapat dilihat nilai Adjusted R Squere adalah 0,380, hal ini berarti 48\%variasidari variabel dependen turnover intention dapat dijelaskan oleh kedua variasidarivariabel independen yaitu kompensasi dan budaya organisasi. Sedangkan sisanya 52\% dijelaskan oleh variabel-variabel lain yang tidak dimasukan dalam model penelitian ini,contohnya: Motivasi, Komitmen Organisasi,KinerjaKaryawan, danGaya Kepemimpinan.

Hasil Uji Ketepatan Model (Uji F). Uji statistik F adalah menunjukkan apakah variabel independen yang dimaksud dalam model mempunyai pengaruh secara bersama-sama terhadap variabel dependennya. Hasil pengujian statistik F dapat dilihat pada Tabel 2 berikut ini.

Tabel 2. Hasil Uji Statistik F

\begin{tabular}{|c|c|c|c|c|c|}
\hline \multicolumn{6}{|c|}{ ANOVA $^{\mathbf{a}}$} \\
\hline Model & Sum of Squares & Df & Mean Square & $\mathrm{F}$ & Sig. \\
\hline Regression & 1019,926 & 2 & 509,963 & 15,100 &, $000^{\mathrm{b}}$ \\
\hline 1 Residual & 1485,947 & 44 & 33,772 & & \\
\hline Total & 2505,872 & 46 & & & \\
\hline
\end{tabular}

a. Dependent Variable: turnover_intention

b. Predictors: (Constant), budaya_organisasi, kompensasi

Berdasarkan Tabel 2 Terlihat nilai $\mathrm{F}$ hitung 15,100 dengan probabilitas 0,000, itu berarti nilai probabilitas $<0,05$, sedangkan hasil yang diperoleh dari $\mathrm{F}$ tabel adalah sebesar 3,21 yang berarti $\mathrm{F}$ hitung $>\mathrm{F}$ tabel $(15,100>3,21)$, sehingga model regresi dapat digunakan untuk memprediksi turnover intention atau dapat disimpulkan bahwan kompensasi dan 
budaya organisasi secara bersama-sama berpengaruh terhadap turnover intention, atau model sudahtepat.

Hasil Uji Hipotesis (Uji Statistik t). Uji statistik t pada dasarnya menunjukkan seberapa jauh pengaruh satu variabel penjelas/ independen secara individual dalam menerangkan variasi variabel dependen.Padauji t, nilai t hitungakandibandingkandengannilai $t$ tabel. Berikuthasilperhitunganuji statistik t yang disajikanpadaTabel 3 sebagai berikut:

Tabel 3. Uji Statistik T

Coefficients $^{\mathbf{a}}$

\begin{tabular}{llrrrrr}
\hline Model & \multicolumn{2}{c}{$\begin{array}{c}\text { Unstandardized } \\
\text { Coefficients }\end{array}$} & \multicolumn{2}{c}{$\begin{array}{c}\text { Standardized } \\
\text { Coefficients }\end{array}$} & T & Sig. \\
\cline { 2 - 5 } & \multicolumn{1}{c}{$\mathrm{B}$} & \multicolumn{1}{c}{ Std. Error } & \multicolumn{2}{c}{ Beta } & & \\
\hline 1 & (Constant) & 8,757 & 8,421 & & 1,040 &, 304 \\
& Kompensasi &,- 145 &, 177 &,- 118 & $-1,816$ &, 000 \\
& budaya_organisasi &,- 547 &, 141 &,- 561 & $-3,885$ &, 000 \\
\hline
\end{tabular}

a .Dependent Variable: Turnover Intention

$$
\mathrm{Y}=8,757-0,145 \mathrm{X}_{1}-0,547 \mathrm{X}_{2}
$$

Dari persamaan regresi di atas maka dapat diinterpretasikan beberapa hal antara lain:

a. Turnover Intention (Y). Variabel terikat yang nilainya akan diprediksi oleh variabel bebas. Pada penelitian ini yang menjadi variabel terikat adalah turnover intention yang nilainya akan diprediksi oleh variabel X1 (Kompensasi) dan variabel X2 (budaya organisasi)

b. Kompensasi X1 terhadap Turnover Intention (Y). Nilai koefisien regresi ini menunjukkan bahwa kontribusi yang diberikan apabila variabel X1 (kompensasi) bernilai negatif artinya setiap peningkatan X1 (Kompensasi) satu satuan maka akan mengurangi tingkat turnover intention (Y) sebesar 0,145 dengan syarat variabel lain konstan.

c. Budaya organisasi (X2) terhadap Turnover Intention (Y). Nilai koefisien regresi ini menunjukkan bahwa kontribusi yang diberikan apabila variabel X2 (budaya organisasi) semakin baik, maka turnover intention (Y) akan berkurang dan koefisien variabel X2 (budaya organisasi) bernilai negatif artinya setiap peningkatan X2 (budaya organisasi) satu satuan maka akan mengurangi tingkat turnover intention (Y) sebesar 0,547 dengan syarat variabel lain konstan.

Berdasarkan Tabel 3 Diperoleh nilai t hitung kompensasi lebih kecil dari nilai t tabel yakni $-1,816<2,01537$ dan nilai signifikasi $0,000<0,05$, jadi kompensasi berpengaruh negatif dan signifikan terhadap turnover intention, nilai t hitung budaya organisasi lebih kecil dari nilai t tabel yakni $-3,885<2,01537$ nilai signifikasi $0,000<0,05$. Jadi budaya organisasi berpengaruh negatif dan signifikan terhadap turnover intention.

Dari hasil uji statistik t tersebut di atas dapat disimpulkan kompensasi berpengaruh negatif dan signifikan terhadap turnover intentionpada PT Hadico Persada.hal tersebut menandakan bahwa kompensasi berpengaruh negatif dan signifikan terhadapturnover intention, yang berarti apabila kompensasi yang di berikan berupa gaji sudah tepat waktu dan pemberian upah lemburan sudah sesuai dengan peraturan yang ada di perusahaan maka niat keluar kerja dari karyawan akan menurun, dan sebaliknya. 
Sedangkan budaya organisasi berpengaruh negatif dan signifikan terhadapturnover intentionpada PT Hadico Persada.hal ini berarti apabila budaya organisasi yang diterapkan sudah sesuaiterutamatentang budaya S3D sudah di implementasikan dengan baik, maka tercipta suasana yang lebih kondusifdanterciptanyateam engagement/ tim yang solid antarsesamakaryawan agar terciptanyakenyamanan di lingkungankerja sehingga dapat memberikan kontribusi yang lebih besar dalam mengurangi tingkat turnover intention.

Pengaruh Kompensasi terhadap Turnover Intention. Berdasarkan hasil perhitungan analisis regresi linier berganda dengan pegujian secara parsial diketahui bahwa variabel kompensasi memperoleh koefisian sebesar $-0,145$, hal ini berarti apabila variabel kompensasi (meningkat 1 satuan, maka turnover intention akan menurun sebesar 0,145 satuan. Hasil pengujian juga menunjukan hasil nilai t hitung sebesar $-1,816$ dan nilai signifikasi sebesar 0,000 . Nilai t hitung lebih kecil dari nilai t tabel 2,01537 dan nilai signifikasi lebih besar dari nilai 0,05 ,

Hasil penelitian ini sejalan dengan penelitian sebelumnya yang dilakukan oleh Putrianti, Arin Dewi (2014) yang membuktikan bahwa kompensasi berpengaruh negatif dan signifikan terhadap turnover intention. Dan penelitian yang di lakukan oleh Devi, Ni Luh Mita Sri dan Sudibia, Gede Adnyana (2015) ditemukan bahwa kompensasi financial berpengaruh negatif dan signifikan terhadap turnover intention.

Pengaruh Budaya Organisasi terhadap Turnover Intention. Berdasarkan hasil perhitungan analisis regresi linier berganda dengan pegujian secara parsial diketahui bahwa variabel budaya organisasi memperoleh koefisian sebesar $-0,547$, hal ini berarti apabila variabel budaya organisasi (meningkat 1 satuan) maka turnover intentionakan menurun sebesar 0,547 satuan. Hasil pengujian juga menunjukan hasil nilai t hitung sebesar $-3,885$ dan nilai signifikasi sebesar 0,000 . Nilai t hitung lebih kecil dari nilai $t$ tabel 2,01537 dan nilai signifikasi kurang dari nilai 0,05, hal tersebut menandakan bahwa budaya organisasi berpengaruh negatif signifikan terhadap turnover intention.

Hasil penelitian ini sejalan dengan penelitian sebelumnya yang dilakukan oleh Kadiman (2012) bahwa budaya organisasi mempunyai pengaruhnegatifdansignifikan terhadap turnover intention. Dan sejalan dengan penelitian Johartono dan Widuri, Retnaningtyas (2013) bahwa budaya organisasi mempunyai pengaruh negatif dan signifikan terhadap turnover intention.

\section{PENUTUP}

Simpulan. Pertama. Kompensasi berpengaruh signifikan terhadap turnover intention pada PT Hadico, hal ini berarti apabila kompensasi meningkat maka turnover intention menurun, sebaliknya jika kompensasi menurun maka turnover intention mengalami peningkatan. Kedua. Budaya organisasi berpengaruh signifikan terhadap turnover intention PT Hadico Persada, hal ini berarti apabila budaya organisasi meningkat maka turnover intention menurun, sebaliknya jika budaya organisasi menurun maka turnoveri ntention mengalami peningkatan.

Saran. Berdasarkan hasil penelitian dan kesimpulan dalam penelitian ini, maka beberapa saran yang perlu disampaikan adalah: (1) Kompensasi yang di berikan kepada 
karyawanterutamaupah lemburan dengan peraturan perusahaanyang ada di perjanjian awal kerja harussesuai,danlebih di perhatikankembalimengenaipemberiangaji yang harus tepat waktu. (2) Kondisi budaya organisasi PT Hadico Persada perlu di tingkatkan lagi, terutama tentang tata nilai S3D agar tercipta suasana yang lebih kondusif dan terciptanya team engagement/ tim yang solid antar sesama karyawan agar terciptanya kenyamanan di lingkungan kerja sehingga dapat memberikan kontribusi yang lebih besar dalam mengurangi tingkat turnover intention. (3) Bagi peneliti berikutnya, sebaiknya menambah variabel-variabel lain yang tidak ada dalam penelitian ini, contohnya: Motivasi, Komitmen Organisasi, Kinerja Karyawan, dan Gaya Kepemimpinan. Sehingga penelitian selanjutnya akan lebih sempurna dan memberikan informasi yang lebih banyak.

\section{DAFTAR PUSTAKA}

Amrullah, Asriyanti. (2012) "Pengaruh Kompensasi Finansial dan Nonfinansial terhadap Kinerja Karyawan PT Bank Rakyat Indonesia (Persero) Tbk, Wilayah Makassar”. Skripsi. Makassar: Fakultas Ekonomi dan Bisnis Universita Hasanuddin.

Bibowo, Adi (2015) "Pengaruh Kepuasan Kerja, Kompensasi, dan Pengembangan Karir terhadap Turnover Intention pada Karyawan Bank Syariah Mandiri cabang Padang". Jurnal Riset Manajemen Bisnis dan Publik, 3 (3): 1-16.

Dessler, Gary, (2007) Manajemen Personalia, Edisi Ketiga, Jakarta: Erlangga.

Devi, Ni Luh Mita Sri (2015) "Analisis Pengaruh Job Insecurity dan Kompensasi Finansial Terhadap Kepuasan Kerja dan Turnover Intention (Studi pada Karyawan Kontrak di Balidynasty Resort)". E-Jurnal Manajemen Unud, 4 (4): 1047-1066, ISSN : 2302-8912.

Duwi Priyanto. (2009) Mandiri Belajar SPSS. Yogyakarta: Mediakom.

Duwi Priyatno, (2011) Buku Saku Analisis Statistik Data SPSS, Yogyakarta,

MediaKom.

E. Jacobs and G. Roodt (2008) "Organisational culture of hospitals to predict turnover intentions of professional nurses".Aarticle in Healt SA Gesondheid, January DOI: 10.4102/hsag.v13i1.258. Source: DOAJ, hal.1-11

Ghozali, Imam. (2006) Aplikasi Analisis Multivariat Dengan Program SPSS, Cetakan Keempat. Badan Penerbit Universitas Diponegoro, Semarang.

Harvey, DF dan D.R. Brown, (2009) An Experiental Approach to Organization Development, Prentice Hall International, New Jersey.

Hasibuan, Malayu. (2012) Manajemen Sumber Daya Manusia, edisirevisi. Jakarta: Bumi Aksara.

Irbayuni, Sulastri (2012) "Pengaruh Kopensasi, Kepuasan Kerja, dan Komitmen Organisasi terhadap Keinginan Untuk Pindah Kerja pada PT Surya Sumber Daya Energi Surabaya". Jurnal NeO-Bis, 6 (1): 1-12.

Johannes, Edward, dan MuchidRofi'i (2014) "Pengaruh Kompensasi dan Iklim Organisasi Terhadap Turnover Intention Dengan Kepuasan Kerja Sebagai Variabel Intervening di PT Trimitra Lestari”. Jurnal Dinamika Manajemen, 2 (2) April-Juni 141:152 ISSN: $2338-123 \mathrm{X}$.

Johartono dan Widuri, Retnaningtyas (2013) “Analisa Pengaruh Stres Kerja, Kepuasan Kerja, Budaya Organisasi, Dan Komitmen Organisasi Terhadap Turnover Intention 
Karyawan Kantor Konsultan Pajak di Surabaya". Jurnal Tax \& Accounting Review, 3 (2): $1-13$.

Kadiman (2012) "Pengaruh Budaya Organisasi, Komitmen Organisasi dan Kepuasan Kerja Terhadap Turnover Intention Karyawan (Studi Kasus pada PT Nyonya Meneer Semarang)".JURAKSI, 1 (1) Januari 2012 ISSN : 2301-9328.

Kartono (Dewi \& Endang, 2008) "Pengaruh kompensasi dan loyalitas karyawan intensi trunover di PT Eramart Group Samarinda". Jurnal eJournal Psikologi. Di ambil pada tanggal $28 \quad$ September 2015 di.http://ejurnal.untagsmd.ac.id/index.php/MTV/article/view/574/763

Lieke. (2008) "Pengaruh kompensasi dan Motivasi Kerja terhadap Komitmen Organisasi". Jurnal eJournal Psikologi.Diambil pada tanggal 28 September 2015 di http://ejurnal.untag-smd.ac.id/index.php/MTV/article/view/574/763

Malayu, S.P. Hasibuan (2007) Manajemen Sumber Daya Manusia, cetakan kesembilan, Jakarta : PT Bumi Aksara.

Malik, Alfian (2014) "Pengaruh Budaya Organisasi dan Loyalitas Kerja dengan Intensi Turnover pada Karyawan PT Cipaganti Heavy Equipment Samarinda". eJournal Psikologi, 2 (1): 65-75 ISSN 0000-0000.

Marwansyah. (2010) Manajemen Sumber Daya Manusia, Edisi Kedua. Bandung:Alfabeta. Putrianti, Arin Dewi (2014) "Pengaruh Kompensasi dan Motivasi Kerja Terhadap Turnover Intention (Studi Pada Karyawan PT TIKI Jalur Nugraha Ekakurir Pusat Malang)". Jurnal Administrasi Bisnis (JAB), 12 (2): 1-9 Juli.

Ridlo, Ilham A, (2012) Turnover Karyawan "Kajian Literatur", Serial Paper Manajemen, Upload Kedua, Public Health Movement, Surabaya.

Robbins SP, dan Judge. (2008) Perilaku Organisasi. Buku 2, Jakarta : Salemba Empat.

Sadili, Samsudin. (2006) Manajemen Sumber Daya Manusia. Bandung: Penerbit Pustaka Setia.

Samsuddin, Sadili. (2006) Manajemen Sumber Daya Manusia. Cetakan Pertama. Bandung: Pustaka Setia.

Sanusi, Anwar (2011) Metode Penelitian Bisnis, Jakarta: Salemba Empat.

Schein, E.H. (2009) Organizational culture and leadership. San Francisco: Jossey-Bass.

Stephen P. Robbins. (2006) Perilaku Organisasi, PT Macanan Jaya cemerlang Indonesia, Jakarta.

Sugiyono. (2013) Metode Penelitian Manajemen. Bandung: Alfabeta.

Sutrisno, Edy. (2012) Manajemen Sumber Daya Manusia. Kencana Prenada Media Group. Jakarta.

Sutrisno, Edy. (2009) Manajemen Sumber Daya Manusia. Jakarta : Kencana Prenada Media.

Tika, Moh. Pabundu. (2006) Budaya Organisasi dan Peningkatan Kinerja Perusahaan. Jakarta: Bumi Aksara.

Toby Marshall Egan, Baiyin Yang, Kenneth R. Bartlett (2004) "The Effects of Organizational Learning Culture and Job Satisfaction on Motivation to Transfer Learning and Turnover Intention". Human Resource Development Quarterly, 15 (3): 279-301.

Umar, Husein. (2010) Riset Pemasaran dan Perilaku Konsumen. Jakarta: Gramedia Pustaka Utama. 
Widjaja, Deborah. C dkk. (2008) “Analisis Persepsi Employee Empowerment Terhadap Employee Turnover Intention Di Hotel X, Kupang, NusaTenggara”. Jurnal Manajemen Perhotelan. 4: 72-84. 
